\title{
Study on Slaughterhouse Wastes Potency and Characteristic for Biogas Production
}

\author{
Budiyono $^{\#}$, I N. Widiasa ${ }^{\# 1}$, S. Johari* and Sunarso* \\ "Department of Chemical Engineering, Faculty of Engineering, Diponegoro University, \\ Jl. Prof. Sudarto, SH No. 1 Semarang \\ Faculty of Animal Agriculture, Diponegoro University, Jl. Prof. Sudarto, SH No. 1 Semarang \\ ${ }^{1}$ budiyono.1966@gmail.com
}

\begin{abstract}
The objective of study was to indentify of the sources and characteristic of slaughterhouse waste for biogas production. The identification waste was done by observing the slaughtering activities on slaughterhouse owned by Regional Government of Semarang City. The wastes studied include the rumen, wastewater, and manure and the characteristics include physical and chemical. Based on the slaughterhouse waste characteristic, either liquid or solid, slaughterhouse waste was very suitable and has high potential to be treated anaerobically for biogas production. The wastewater has the potency for producing total biogas as $2.472 \mathrm{~m}^{3} / \mathrm{m}^{3}$ of wastewater. The degradation of cattle manure has the potency for producing total biogas of $618,90 \mathrm{~L} / \mathrm{kg}$ in dry based by the composition of $\mathrm{CH}_{4}$, $\mathrm{CO}_{2}, \mathrm{NH}_{3}$ were $48.89,47.87$, and $2.43 \%$ volume, respectively. In other terms, cattle manure will produce $\mathrm{CH}_{4}$ as $305.06 \mathrm{~L} / \mathrm{kg}$ in dry based.
\end{abstract}

Keywords: anaerobic digestion, biogas production, rumen fluid, slaughterhouse wastes

\section{INTRODUCTION}

In rural areas of developing countries such as Indonesia various cellulosic biomass (cattle dung, agricultural residues, etc.) are available in plenty which have a very good potential to cater to the energy demand, especially in the domestic sector. In addition, as an agricultural country, Indonesia has an abundance biomass wastes generated by animal agricultural activities, including several activities at slaughterhouse (Budiyono et al., 2007).

Due to the development of anaerobic digestion (AD) processes, these biomasses have great potential to contribute considerably the renewable energy such as biogas. In addition, these $\mathrm{AD}$ processes are also simultaneously resolving ecological and agrochemical issues. For example, besides covering environmental problems due to waste disposal, the $\mathrm{AD}$ of manure for biogas production does not reduce its value as a fertilizer, as available nitrogen and other substances remain in the treated sludge (Alvarez and Lide'n, 2008).

Originally, Indonesian country is the net-exporter of fuel oil. However, began in July 2004, Indonesia shifted from a net oil exporter to a net importer. This is due to decline in production, coupled with lower exploration investment level and increase of fuel consumption (Prihandana and Hendroko, 2007). In effort to anticipate the increasing of energy problem in Indonesia, the Indonesian government has formulated the strategic national energy regulation via Indonesian President Regulation No. 5 year 2006 (Per Pres RI, 2006). Basically, Indonesian government has made the national energy regulation based on price regulation, energy conservation, and energy diversification. Energy diversification is the use of alternative energy such as energy from biomass termed as biogas.

Due to the abundant biomass wastes generated by slaughterhouse, these biomass resources potential for biogas production are very attractive to be reviewed and discussed. The objective of this research was to study the potency and characteristics of slaughterhouse wastes for biogas production.

\section{MATERIALS AND METHODS}

The observation study was carried out to characterize the slaughterhouse wastes. The waste characteristics especially include both physical and chemical.

Sample preparation. The cattle manures and liquid rumens were taken randomly from slaughterhouse located on Semarang city. The fresh raw manure was collected from animal holding pen unit in the slaughterhouse. Rumen was collected from evisceration unit of slaughterhouse. The sampling was done four times in a certain days with duplo analysis. The sample obtained was brought to laboratory as soon as so didn't require sample preservation. Liquid rumen preparation was as follows: rumen content was poured to 100 $\mathrm{ml}$ tank and added tap water until water level near full. Solid content then be separated from slurry by filter cloth. To assure that solid content in solution were dominated by bacteria, solution obtained then was filtered by 50 micron cartridge filter. Solution obtained was analyzed for characterization.

Analytical procedures. The parameters analyzed from cattle manure were as follows: Total Nitrogen (TN), Dry Matter (DM), Volatile Solid (VS), protein, carbohydrate, lipid, raw fiber, ADF (Acid Detergent Fiber), NDF (Neutral Detergent Fiber), and ADL (Acid Detergent Lignin). TN was analyzed using the Kjeldahl standard method (APHA, 1996). $\mathrm{DM}$ was measured after drying at $105^{\circ} \mathrm{C}$ for $24 \mathrm{~h}$, and ash after heating to $525{ }^{\circ} \mathrm{C}$ for $5 \mathrm{~h}$. VS was determined by subtracting the amount of ash from the amount of dry matter. ADF was measured as the amount of suspended VS after removing dissolved material following boiling with a detergent in $0.5 \mathrm{~mol} / \mathrm{L} \mathrm{H}_{2} \mathrm{SO}_{4}$ (Van Soest, 1963). The lipid content was analyzed by measuring the amount of material that could be extracted with diethyl ether in a Sohxhlet extraction instrument after hydrolysis with $3 \mathrm{~N}$ hydrochloric acid. The lignin content was analyzed by determination of suspended VS after boiling with a detergent in sulphuric acid followed by suspension in $72 \%$ sulphuric acid for $48 \mathrm{~h}$ (Van Soest, 1963). The protein content was determined by multiplying the difference between $\mathrm{TN}$ and $\mathrm{NH} 4-\mathrm{N}$ by a 
factor of 6.25 . The carbohydrate was calculated by subtracting protein, lignin, and lipids from the VS content.

Wastewater and liquid rumen was characterized by analyzing pH, TS, VS, Total Suspended Solid (TSS), Volatile Suspended Solid (VSS), and Chemical Oxygen Demand (COD) using Standard Methods for the Examination of Water and Wastewater (APHA, 1996).

Data analysis. Data analysis was carried out by using the software package SPSS, version 11.5 (SPSS Inc., 2005). Each treatment was measured in three replicates. In a first step, the data are summarized by descriptive statistics. Means, standard deviation and frequency distributions of the data was determined. Variance analysis methods were applied to find significant differences in the means.

\section{RESULTS AND DISCUSSIONS}

The results of identification showed that the slaughterhouse wastes was generated from different activities in the slaughterhouses such as holding and washing animals, bleeding out, skinning, cutting and boning, cleaning of rooms, etc. The wastewater contained blood, particles of skin and meat, rumen fluid content, urine, manure, and other pollutants origin from floor washing. Slaughterhouse wastewater is rich in both soluble and insoluble organic compounds and comprises large quantities of putrefactive and bulky sludge that requires special handling or treatment.

\section{A. The characteristic of wastewater.}

Data concerning wastewater caharateristic was obtained from 4 (four) times sampling periode and measurement. The wastewater composition obtained from this study was compared to several researchers before is presented in Table 1.

Table 1 shows that, in general, the characteristic of wastewater obtained from this research were more and less in the range of the concentration resulted by several researcher before. The pH, Biological Oxygen Demand (BOD), Chemical Oxygen Demand (COD), and suspended solids (SS) resulted in this study were $7.19 \pm 0.06,1,873 \pm 421,3,756 \pm 687$, and $1,171 \pm 311 \mathrm{mg} / \mathrm{L}$, respectively. While Nitrogen total, Amonia, and protein were $212 \pm 106,3.03 \pm 1.77$, and 1,303 $\pm 653 \mathrm{mg} / \mathrm{L}$, respectively. The variation of the strenght and characteristics of waste from several researchers and also this study caused by several factors such as production capacity of slaghterhouse, type and weight of animal, methods of transportation, animal recieving and holding, processing technology, amount of carcase, washing temperature, cleaning and sanitazing procedure, and labours behaviour (WRRC, 1995).

TABLE 1

SLAUGHTERHOUSE WASTEWATER CHARACTERISTICS

\begin{tabular}{|c|c|c|c|c|c|c|c|c|c|}
\hline \multirow{2}{*}{ Para-meter } & \multirow{2}{*}{ unit } & \multicolumn{8}{|c|}{ Average concentration / Researcher $\left.{ }^{*}\right)$} \\
\hline & & 1 & 2 & 3 & 4 & 5 & 6 & 7 & This study \\
\hline $\mathrm{pH}$ & - & 7.1 & 7.2 & 6.7 & 7.3 & 6.05 & 6.9 & 7.5 & $7.19 \pm 0.06$ \\
\hline BOD & $\begin{array}{c}\mathrm{mg} \\
\mathrm{O}_{2} / \mathrm{L}\end{array}$ & - & 900 & 11,000 & - & 6,000 & 2,250 & - & $1,873 \pm 421$ \\
\hline COD & $\begin{array}{c}\mathrm{mg} \\
\mathrm{O}_{2} / \mathrm{L}\end{array}$ & 11,500 & 1,820 & 27,500 & $\begin{array}{c}8,20 \\
0\end{array}$ & 12,975 & 4,175 & 12,820 & $3,756 \pm 687$ \\
\hline $\begin{array}{l}\text { Suspended } \\
\text { solid }\end{array}$ & $\mathrm{mg} / \mathrm{L}$ & 2,658 & 430 & 1,020 & $\begin{array}{c}1,13 \\
0\end{array}$ & 3,550 & 1,300 & 58,200 & $1171 \pm 311$ \\
\hline Total Nitrogen & $\mathrm{mg} / \mathrm{L}$ & 735 & 190 & - & - & 381 & 120 & 531 & $212 \pm 106$ \\
\hline Amonia - N & $\mathrm{mg} / \mathrm{L}$ & 221 & - & - & 46.5 & 212.5 & - & - & $3.03 \pm 1.77$ \\
\hline Protein & $\mathrm{mg} / \mathrm{L}$ & 3,213 & - & - & $\begin{array}{c}5,50 \\
0\end{array}$ & - & - & - & $1,303 \pm 653$ \\
\hline
\end{tabular}

*) 1: Masse, D.I dan L. Masse (2001); 2: Pozo,R.D dan Diez,V (2005); 3: Kobya,M. Et al (2006); 4 : Rajeswari, K.V et al (2000); 5: Fuchs,W et al. (2003); 6: Ma

Table 1 also shows that slaughterhouse wastewater contains high organic matter presented as COD and BOD. High ratio of $\mathrm{BOD} / \mathrm{COD}$ about 0.5 presents organic matters contained by slaughterhouse wastewater are highly biodegradable. Hence, the organic matter contained will easily used by micoorganisms either in aerobic or anaerobic condition. Furthermore, slaughterhouse wastewater will be very harmful to the environment if discharged directly to the environment without proper treatment. Effluent discharge from slaughterhouses will cause the deoxygenation of rivers (Quinn and Farlane 1989) and the contamination of groundwater (Sangodoyin and Agbawhe, 1992). Slaughterhouse wastewater also contains high concentrations of SS include pieces of fat, grease, hair, feathers, manure, grit, and undigested feed. These insoluble materials will contribute the slowly biodegradable of organic matter (Sayed et al., 1988).

\section{B. Characterization of solid waste}

Generally, slaughterhouse solid wastes consists of animal manure, skin, bone, meat, and hair. The characteristic of manure is presented by proximate analysis and fiber analysis (Van Soest). The results of 4 (four) time sampling and measurement are shown in Table 2 and Table 3.

Table 2 shows that cattle manure average contain average raw lipid, raw fiber and raw protein were $1.51 \pm 0.75,44.44 \pm 2.49$, and $8.28 \pm 1.54 \%$ (dry based), repectively. In other term, cattle manure contains average organic and anorganic content $79.94 \pm 2.68$ and $21.06 \pm 2.78 \%$ (dry based), respectively. In addition, water, TS, and VS content in fresh manure were $79.77 \pm 1.94,20.23 \pm 1.94$, and $18.11 \pm 1.70 \%$ (wet based), respectively.

Table 3 shows that manure contained lignin, cellulose, hemicelluloses, and total lignocellulosic materials were $25.97 \pm 11.13, \quad 35.57 \pm 8.76, \quad 14.94 \pm 4.80$, and $76.49 \pm 7.81 \%$, respectively. Lignin, cellulose, hemicelluloses, and total 
lignocellulosic materials were complex chemical compound most commonly derived from all plant cell walls. The presence of these components in manure was originated from animal feed dominated by agricultural waste or residu. Hence, animal manure can be viewed as compex substrate contains either organic materials such as carbohydrate, protein, and lipid or anorganic material. Organic materials content in catlle manure can be presented by chemical formula of $\mathrm{C}_{6} \mathrm{H}_{10} \mathrm{O}_{5}$ for soluble component and $\mathrm{C}_{6} \mathrm{H}_{10} \mathrm{O}_{5} \cdot \mathrm{nNH}_{3}$ for unsoluble fraction (Angelidaki and Sanders, 2004). In addition, fiber comprising lignin, cellulose, and hemicellulose is the main component of animal manure.

TABLE 2

PROXYMATE ANALYSIS OF CATTLE MANURE (DRY BASIS)

\begin{tabular}{|c|c|c|c|c|c|}
\hline \multirow{2}{*}{$\begin{array}{c}\text { Componennt, } \\
\%\end{array}$} & \multicolumn{5}{|c|}{ Measurement } \\
\hline & 1 & 2 & 3 & 4 & Average \\
\hline Ash content & 22.03 & 21.36 & 20.89 & 15.94 & $20.06 \pm 2.78$ \\
\hline Raw Lipid & 2.52 & 1.41 & 1.38 & 0.71 & $1.51 \pm 0.75$ \\
\hline Raw Fiber & 43.11 & 47.02 & 45.98 & 41.65 & $44.44 \pm 2.49$ \\
\hline Raw Protein & 6.40 & 9.97 & 8.96 & 7.79 & $8.28 \pm 1.54$ \\
\hline $\begin{array}{l}\text { NFE } \\
\text { (Nitrogen } \\
\text { Free Extract) }\end{array}$ & 25.94 & 20.23 & 22.79 & 33.92 & $25.72 \pm 5.94$ \\
\hline $\begin{array}{l}\text { Volalite Solid } \\
\text { (VS), \%DM }\end{array}$ & 77.97 & 78.64 & 79.11 & 84.06 & $79.94 \pm 2.78$ \\
\hline Water $\left.{ }^{*}\right)$ & 81.76 & 77.10 & 80.23 & 79.99 & $79.77 \pm 1.94$ \\
\hline Dry Matter ${ }^{*}$ & 18.24 & 22.90 & 19.77 & 20.01 & $20.23 \pm 1.94$ \\
\hline $\begin{array}{l}\text { Volatile } \\
\text { Solid, VS*) }\end{array}$ & 16.03 & 20.16 & 17.88 & 18.35 & $18.11 \pm 1.70$ \\
\hline
\end{tabular}

Remarks: *) wet based/fresh manure

TABLE 3

VAN SOEST ANALYSis OF CATtLe MANuRE

\begin{tabular}{|c|c|c|c|c|c|}
\hline \multirow{2}{*}{$\begin{array}{c}\text { Parameter, } \\
\%\end{array}$} & \multicolumn{5}{|c|}{ Measurement } \\
\hline & 1 & 2 & 3 & 4 & Average \\
\hline $\mathrm{ADF}$ & 66.51 & 59.22 & 59.60 & 60.85 & $61.54 \underline{+3.38}$ \\
\hline $\mathrm{NDF}$ & 87.93 & 74.95 & 70.99 & 72.07 & $76.49 \pm 7.81$ \\
\hline $\mathrm{ADL}$ & 40.69 & 28.12 & 19.53 & 15.55 & $25.97 \pm 11.13$ \\
\hline Lignin (ADL) & 40.69 & 28.12 & 19.53 & 15.55 & $25.97 \pm 11.13$ \\
\hline $\begin{array}{l}\text { Cellulose } \\
\text { (ADF-ADL) }\end{array}$ & 25.82 & 31.10 & 40.07 & 45.30 & $35.57 \pm 8.76$ \\
\hline $\begin{array}{l}\text { Hemicellulose } \\
\text { (NDF-ADF) } \\
\text { Total }\end{array}$ & 21.43 & 15.73 & 11.39 & 11.22 & $14.94+4.80$ \\
\hline $\begin{array}{l}\text { lignocellulosic } \\
\text { materials } \\
\text { (NDF) }\end{array}$ & 87.93 & 74.95 & 70.99 & 72.07 & $76.49 \pm 7.81$ \\
\hline
\end{tabular}

\section{Potency of slaughterhouse for biogas production}

As has been stated before, the organic matters contained by slaughterhouse waste have the special characteristic i.e. highly biodegradable and easily used by micoorganisms either in aerobic or anaerobic condition. However, anaerobic digestion is the best option with several advantages are: (1). a high efficiency in reducing COD in soluble and insoluble form; (2). a low sludge production of only $5 \%$ to $20 \%$ of that generated by aerobic systems; (3). the recovery of usable energy in the form of methane; (4). no aeration energy requirement; (5). no chemical handling; (6). the biomass can remain unfed for long periods without deterioration (Speece, 1996).

All COD contained by waste are able to be converted to be methane with equivalency according to the reaction as follows:

$$
\mathrm{CH}_{4}+2 \mathrm{O}_{2}--->\mathrm{CO}_{2}+2 \mathrm{H}_{2} \mathrm{O}
$$

According to the above reaction, if 1 gram COD degraded on $35{ }^{\circ} \mathrm{C}$ and $1 \mathrm{~atm}$ produce $395 \mathrm{ml} \mathrm{CH}_{4}$ (Speece, 1996). The wastewater characteristic as presented in Table 8 (COD $3,756 \pm 687 \mathrm{mg} / \mathrm{L}$ ) give methane as $1.483 \pm 0.271 \mathrm{~m}^{3} / \mathrm{m}^{3}$ of wastewater. In other term, if assumed that total biogas contained $60 \%$ methane, total biogas produced will be $2.472 \pm 0.451 \mathrm{~m}^{3} / \mathrm{m}^{3}$ of wastewater. Furthermore, if assumed that wastewater released equivalent to $0.9 \mathrm{~m}^{3} /$ animal unit slaughtered, total biogas production will be $2.225 \pm 0.406$ $\mathrm{m}^{3}$ /animal unit slaughtered.

The potency of cattle manure for biogas production is able to be explained as follows. The formation of methane from biomass follows in general the equation:

$$
\begin{aligned}
& \mathrm{C}_{\mathrm{c}} \mathrm{H}_{\mathrm{h}} \mathrm{O}_{\mathrm{o}} \mathrm{N}_{\mathrm{n}} \mathrm{S}_{2}+\left[\frac{4 c-\mathrm{h}-20+3 \mathrm{n}+3 \mathrm{~s}}{4}\right] \mathrm{H}_{2} \mathrm{O}===== \\
& \left\lceil\frac{4 \mathrm{c}+\mathrm{h}-2 \mathrm{o}-3 \mathrm{n}-2 \mathrm{~s}}{8}\right] \mathrm{CH}_{4}+\left[\frac{4 \mathrm{c}-\mathrm{h}+2 \mathrm{o}+3 \mathrm{n}+2 \mathrm{~s}}{8}\right] \mathrm{CO}_{2}+\mathrm{nNH}_{3}+\mathrm{sH}_{2} \mathrm{~s}
\end{aligned}
$$

As presented in Table 2, cattle manure consists of organic and inorganic component i.e. contain average ash, raw lipid, raw fiber and raw protein content of $20.06 \pm 2.78,1.51 \pm 0.75$, $44.44 \pm 2.49$, and $8.28 \pm 1.54 \%$ (dry based), respectively. According to equation (2), the reaction products from several components are as follows:

$$
\begin{aligned}
& \text { Carbohydrate: } \mathrm{C}_{6} \mathrm{H}_{12} \mathrm{O}_{6}======33 \mathrm{CH}_{4}+3 \mathrm{CO}_{2} \\
& \text { Fats: } \mathrm{C}_{12} \mathrm{H}_{24} \mathrm{O}_{6}+9 \mathrm{H}_{2} \mathrm{O}=====>4.5 \mathrm{CH}_{4}+7.5 \mathrm{CO}_{2} \\
& \text { Proteins: } \mathrm{C}_{13} \mathrm{H}_{28} \mathrm{O}_{7} \mathrm{~N}_{3} \mathrm{~S}+6 \mathrm{H}_{2} \mathrm{O}=>6.5 \mathrm{CH}_{4}+6.5 \mathrm{CO}_{2}+3 \mathrm{NH}_{3}+\mathrm{H}_{2} \mathrm{~S}
\end{aligned}
$$

From equation (3), theoretical methane yields (STP ml $\mathrm{CH}_{4} / \mathrm{g}$ ) from organic compounds can be predicted based on the stoichiometric conversion of organic matter to methane and carbon dioxide. In case of cattle manure contain average ash, raw fat, fiber and protein content of $20.06 \pm 2.78,1.51 \pm 0.75$, $44.44 \pm 2.49$, and $8.28 \pm 1.54 \%$ (dry based) respectively as presented in Table 2, each kg of cattle manure produce biogas in dry based as presented in Table 4 . In Table 4, ideally, the degradation of cattle manure produce $619.90 \mathrm{ml}$ total biogas per gram in dry based by the composition of $\mathrm{CH}_{4}, \mathrm{CO}_{2}, \mathrm{NH}_{3}$ are 48.89, 47.87, and $2.43 \%$ volume, respectively. According to Angelidaki and Sanders (2004), the calculated theoretical methane yield of manure was $0.40\left(\mathrm{~m}^{3} / \mathrm{kgVS}\right.$ added), while according to Hansen et al. (2004) the methane potential of the several organic wastes tested was in the range of $200-500 \mathrm{ml}$ $\mathrm{CH}_{4} / \mathrm{g}$ VS.

If assumed that cattle excrete $20 \mathrm{~kg}$ manure/(animal unit.day) by the composition of $20 \%$ dry matter, the biogas produced will be $2,476 \mathrm{~m}^{3}$ per unit animal. However, all of manure constituents are not completely degraded or converted to gas through anaerobic digestion. Anaerobic bacteria do not 
degrade lignin and some other hydrocarbons. Several studies had shown that lignin rich waste rather difficult to be degraded (Wilkie, 2005). Finally, the conclusion can be drawn that, based on slaughterhouse waste characteristic, either liquid or solid, slaughterhouse waste was very potenial to be treated anaerobically for biogas production.

TABLE 4

Calculation Of Biogas Production Per Gram Cattle Manure (Dry Based)

\begin{tabular}{|c|c|c|c|c|c|c|c|c|}
\hline \multirow{2}{*}{ Comp'nts } & \multirow{2}{*}{$\begin{array}{l}\text { Weight } \\
\text { fraction }\end{array}$} & \multicolumn{5}{|c|}{ Biogas production, ml (STP) } & \multicolumn{2}{|c|}{ Biogas comp. } \\
\hline & & $\mathrm{CH}_{4}$ & $\mathrm{CO}_{2}$ & $\mathrm{NH}_{3}$ & $\mathrm{H}_{2} \mathrm{~S}$ & Total & Comp't & $\%$ volume \\
\hline Ash & 0.20 & - & - & - & - & - & & \\
\hline Carbohydrate & 0.70 & 261.33 & 261.33 & 0.00 & 0.00 & 522.67 & $\mathrm{CH}_{4}$ & 48.89 \\
\hline Raw Protein & 0.08 & 34.11 & 31.59 & 15.16 & 5.05 & 80.86 & $\mathrm{CO}_{2}$ & 47.87 \\
\hline \multirow[t]{2}{*}{ Raw Fat } & 0.02 & 9.61 & 5.77 & 0.00 & 0.00 & 15.37 & $\mathrm{NH}_{3}$ & 2.43 \\
\hline & & & & & & & $\mathrm{H}_{2} \mathrm{~S}$ & 0.81 \\
\hline Total : & & 305.06 & 298.68 & 15.16 & 5.05 & 618.90 & & 100 \\
\hline
\end{tabular}

\section{IV.CONCLUSIONS}

Based on the characteristic slaughterhouse waste, either liquid or solid, slaughterhouse waste was very suitable and has high potential to be treated anaerobically for biogas production. The wastewater has the potency for producing total biogas as $2.472 \mathrm{~m}^{3} / \mathrm{m}^{3}$ of wastewater. Based on wastewater generated by slaughterhouse activities, total biogas produced will be $2.225 \mathrm{~m}^{3}$ /animal unit slaughtered. Cattle manure has the potency for producing total biogas of 619.90 $\mathrm{L} / \mathrm{kg}$ in dry based by the composition of $\mathrm{CH}_{4}, \mathrm{CO}_{2}, \mathrm{NH}_{3}$ are 48.89, 47.87, and 2.43\% volume, respectively. Based on animal unit of cattle slaughtered, the biogas produced will be $2,476 \mathrm{~m}^{3}$ per unit animal per day in animal holding pen.

\section{REFERENCES}

[1]. Alvarez, R. and G. Lide'n. 2008. The effect of temperature variation on biomethanation at high altitude, Bioresource Technology 99: 72787284

[2]. American Public Health Association (APHA). 1996. Standard Methods for Examination of Water and Wastewater. 17th ed., Washington.

[3]. Angelidaki, I. and Sanders, W. 2004. Assessment of the anaerobic biodegradability of macropullants. Rev. Environ. Sci. Bio.Technol. 3: $117-129$

[4]. Batstone, D.J., J. Keller, R.B. Newell, and M. Newland. 2000. Modeling anaerobic degradation of complex waste water. I: model development. Bioresour. Technol. 75: 67-74.

[5]. Budiyono, I N. Widiasa, and Sunarso. 2007. Perkembangan Teknolog Pengolahan Air Limbah Rumah Pemotongan Hewan (RPH): Overview, Prosiding Seminar Nasional Fundamental dan Aplikasi Teknik Kimia, ITS Surabaya, pp. PL11 1-7

[6]. Caixeta, C.E.T., M.C. Cammarota, and A.M.F. Xavier. 2002. Slaughterhouse wastewater treatment: evaluation of a new three-phase separation system in a UASB reactor, Bioresour. Technol. 81(1):61-69.

[7]. Fuchs, W., H. Binder, G. Mavrias, and R. Braun. 2003. Anaerobic treatment of wastewater with high organic content using a stirred tank reactor coupled with a membrane filtration unit. Water Res. 37(4):902908.

[8]. Kobya, M., E. Senturk, and M. Bayramoglu. 2006. Treatment of poultry slaughterhouse wastewaters by electrocoagulation. J. Hazardous Materials, B133:172-176.

[9]. Manjunath, N.T., I. Mehrotra, and R.P. Mathur. 2000. Treatment of wastewater from slaughterhouse by DAF-UASB system. Water Res. 34(6):1930-1936
[10]. Massé D.I. and L. Masse. 2001. The effect of temperature on slaughterhouse wastewater treatment in anaerobic sequencing batch reactors. Bioresour. Technol. 76(2):91-98

[11]. Massé, D.I. And L. Masse. 2000. Characterization of wastewater from hog slaughterhouses in Eastern Canada and evaluation of their in-plant wastewater treatment systems, Canadian Agricultural Engineering, 42(3): 139-146

[12]. Nielsen, H.B., Z. Mladenovska, P. Westermann, and B.K. Ahring. 2004. Comparison of two stage thermophilic $\left(68{ }^{\circ} \mathrm{C} / 55^{\circ} \mathrm{C}\right)$ anaerobic digestion with one stage thermophilic $\left(55^{\circ} \mathrm{C}\right)$ digestion cattle manure. Biotechnol. and Bioeng. 86(3):291-300.

[13]. Nunez, L.A. and B. Martinez. 1999. Anaerobic treatment of slaughterhouse wastewater in an expanded granular sludge bed (EGSB) reactor, Water Science and Technology, 40(8):99-106.

[14]. Peraturan Presiden Republik Indonesia (Per Pres RI). 2006. Per Pres RI No. 5 Tahun 2006 tentang Kebijakan Energi Nasional, Jakarta.

[15]. Pozo, R.D., and V. Diez. 2005. Integrated anaerobic-aerobic fixed-film reactor for slaughterhouse wastewater treatment. Water Res. 39(6):1114-1122.

[16]. Prihandana, R. and R. Hendroko. 2007. Energi Hijau, Penebar Swadaya, Jakarta, pp. 11-14.

[17]. Quinn J.M. and P.N. McFarlane. 1989. Effects of slaughterhouse and dairy factory wastewaters on epilithon: A comparison in laboratory streams. Water Research, 23:1267-1273

[18]. Sadaka,S.S. and C.R. Engler. 2003. Effect of initial total solids om composting of raw manure with biogas recovery, Compost Science and Utilization, 11(4):361-369.

[19]. Sarapatka, B. 1993. A study of produksi biogas during anaerobic fermentation of farmyard manure. Biomass and Bioenergy, 5(5):387393.

[20]. Sayed, S.K.I., J. van der Zanden, R. Wijffels, and G. Lettinga. 1988. Anaerobic degradation of the various fractions of slaughterhouse wastewater. Biological Wastes, 23:117-142.

[21]. Speece, R.E. 1996. Anaerobic Technology for Industrial Wastewaters. Archae Press, Tennessee, 9-20. SPSS Inc. 2005.

[22]. SPSS Software, Release 11.5. SPSS Inc., Chicago

[23]. Van Soest, P.J. 1963. Use of detergents in the analysis of fibrous feeds. Journal of AOAC International 46, 825-835

[24]. Wilkie, A.C. 2005. Anaerobic Digestion of Dairy Manure: Design and Process Consideration, dalam Dairy Manure Management : Tretament, Handling, and Community Relations, Natural Resource, Agriculture, and Engineering Service, Cornell University, Itaca, p. 301-312.

[25]. WRRC (Waste Reduction Resource Center). 1995. Environmental Impacts from Meat and Fish Processing, http://wrrc.p2pays.org/p2rx/nav.cfm?hub=449\&subsec=10 